\title{
Development of fermented pumpkin porridge as a meal replacement
}

\author{
Jung Suk Park ${ }^{1}$, Hwan Sik $\mathrm{Na}^{2 *}$ \\ ${ }^{1}$ Department of Complementary and Alternative Medicine, Kwang-ju Womens University, Gwangju 62396, Korea \\ ${ }^{2}$ Agricultural Products Inspection Center, Jeollanamdo Institute of Health and Environment, Muan 58568, Korea
}

\section{호박을 이용한 식사대용식 발효 호박죽 제조}

\author{
박정숙 ${ }^{1} \cdot$ 나환식 $^{2 *}$ \\ ${ }^{1}$ 광주여자대학교 대체의학과, ${ }^{2}$ 전라남도보건환경연구원 농산물검사소
}

\begin{abstract}
This study was performed to investigate the effects on addition rate of dried pumpkin leaf and seed to pumpkin porridge, as well as to examine the quality characteristics of fermented pumpkin poridge. For enzyme activities amylase and protease from fermented pumpkin ponidge were examined. Fermented pumpkin porridge was prepared with different amount of pumpkin leaf and seed powder in the ratio of $0.25,0.5$, or $1.0 \%$ according to the quantity of porridge. With an increase in the quantity of fermented pumpkin leaf and seed powder added, the carbohydrate and crude protein contents of pumpkin ponidge increased, whereas the crude lipid contents decreased. The total sugar contents in the control sample (without fermented pumpkin powder) was higher $(26.23 \pm 2.15 \%)$ than that of the others (18.31-19.05\%). Major free sugars in the samples were sucrose, glucose and fructose. The total free sugar contents in the control samples was higher $(36.54 \pm 1.41 \%)$ than that in the other samples containing fermented pumpkin porridge powders. The Hunter's $L$, a, and b value decreased as the contents of fermented pumpkin leaf and seed powder increased. Our results reveal that, adding fermented pumpkin leaf and seed powder could improve the quality of pumpkin porridge and addition of $1 \%$ powder is optimal.
\end{abstract}

Key words : pumpkin, pumpkin leaf, pumpkin seed, fermentation, porridge

\section{서 론}

호박(Cucurbita spp.)은 박과에 속하는 1년 생 덩굴식물로 서 열대 아메리카가 원산지이며 크게 서양계 호박인 단호박 (Cucurbitamaxima D.)과 페루계 호박(Cucurbita pepo L.) 그리고 동양계 호박인 늙은 호박(Cucurbita moschata D.)으 로 나누어진다(1). 호박에는 소화 흡수성이 높은 당류와 풍부한 섬유질과 황색을 나타내는 천연색소인 carotenoid계 화합물이 다량 존재하며, 항암에 효과가 있는 $\beta$-carotene의 함량이 높아 최근 기능성 소재로서 관심이 높아지고 있다(2)

*Corresponding author. E-mail : hsna0103@korea.kr Phone : 82-61-720-1651, Fax : 82-61-720-1659

Received 26 July 2018; Revised 16 August 2018; Accepted 17 August 2018.

Copyright (c) The Korean Society of Food Preservation. All rights reserved.
호박은 위가 약하고 마른 사람, 회복기 환자, 임산부의 부기를 빼고, 당뇨, 고혈압, 전립선 비대에 효과가 있으며 (3), 다양한 암의 발생 위험을 감소시키는 효과가 있는 것으 로 알려져 있다(4). 주로 열매, 잎, 종자 등 다양한 부위가 식용으로 이용되고 있으며, 특히 열매 부위는 칼륨, 티아민 등의 주요 급원으로 알려져 있다. 하지만 수확 후 당도가 높아 저장성이 매우 약하고 유통기간 중 제품의 품질저하가 초래되어 장기 저장하는 방법과 가공이용에 대한 연구가 요구되고 있다(5).

호박잎 부위 또한 우리나라에서 식용으로 이용되고 있는 데 열매보다 그 섭취 빈도는 낮으나 칼슘 함량은 약 6-45배 높아 나트륨 배출에 효과적이며, 타 부위보다 칼로리가 낮 고 섬유질이 많아 변비와 다이어트에 좋으며, 폴리페놀 및 플라보노이드 함량, radical 소거 활성, 환원력, tyrosinase 활성 저해능 등이 높은 것으로 보고되어 호박잎의 기능성이 조명된 바 있다(6-9). 
또한, 호박의 씨에는 비타민 B, C, E와 효소인 urease가 들어 있고, 인, 철, 마그네슘이 풍부하며, 기름이 약 40-50\% 가량 함유하고 있는 것으로 알려져 있다(10). 호박씨에 함유 된 기름의 주성분은 리놀산, 올레산, 팔미트산, 스테아르산 으로 대부분은 불포화지방산인 리놀산과 올레산으로 이루 어져 있으며, 리놀산은 항염증 작용, 올레산은 상처 치료, 면역 및 염증 질환에 효과가 있는 것으로 알려져 있다 (11-13).

죽은 곡물에 물을 많이 붓고 오랫동안 끓여서 곡식의 알이 부드럽게 퍼지고 곡식의 주성분인 녹말이 완전히 호화 상태가 되도록 만든 유동식의 음식으로 소화되기 쉬운 상태 까지 무르게 익은 음식을 총칭하는 말이다(14). 이러한 죽이 식생활이 바뀌면서 우리나라의 전통 음식인 죽이 환자식 또는 회복식으로 인식되고 있었다. 하지만 근래에 들어 환 자식이나 회복식이라는 기존의 고정관념에서 벗어나 건강 하면서도 간편하고 남녀노소 누구나 한 끼 식사대용으로 즐길 수 있는 대중화된 외식 중 하나로 발전되었다(15).

요즘에는 죽이 기존의 용도 이외에도 식사 전의 에피타 이져나 일종의 스프 대용으로 이용되며, 통조림 또는 인스 턴트식품으로도 개발되어 다양한 종류로 시판되고 있어 죽이 이용률이 더욱 높아졌다. 이러한 죽은 조리가 쉽고 간편하게 먹을 수 있으면서 식사시간도 많이 소요되지 않고 부재료의 첨가 등으로 다양하게 즐길 수 있는 장점이 있다. 또한 다양한 부재료를 첨가하여 제조한 죽은 영양적인 면에 서도 우수하고 소화 - 흡수도 용이하여 다른 음식에 비하여 경쟁력이 있고 개발 가능성이 있다고 판단된다.

호박죽은 사람들에게 여러 가지 효능과 영양이 알려지면 서 다양한 연구가 시도되어 왔다. 호박죽에 관한 선행 연구 로는 호박죽의 재료변화와 배합비에 따른 기호도 연구(16), 호박 재료 배합비율을 달리한 호박죽의 품질 특성 연구(2), 반응표면분석법을 이용한 호박 분말 첨가 즉석 호박죽의 최적화(17) 등이 진행되어 왔다. 여러 가지 효능이 알려진 호박으로 제조한 한국 전통 음식인 호박죽의 연구를 통하여 재료의 정확한 계량과 레토르트로 제조하기 위한 재료 배합 비 개발을 통해 호박죽의 기호도를 높이고 섭취의 편리성을 높이는 연구가 필요할 것으로 판단된다.

따라서 본 연구에서는 기존의 호박죽 제조에 호박만이 사용되었던 것에 비해 다양한 효능을 가진 호박의 부산물인 호박잎과 씨를 첨가하여 제조한 호박죽의 재료 배합비 등의 개발과, 발효 공정을 첨가하여 제조한 발효 호박죽 제품의 영양학적 특성을 조사함으로써 새로운 호박죽 제품에 대한 소비를 촉진하고, 최적의 배합비 개발을 통해 호박죽의 영 양과 기호도를 높이고자 실시하였다.

\section{재료 및 방법}

\section{실험 재료}

실험에 사용된 늙은호박(고흥산), 단호박(고흥산), 호박
잎(고흥산), 호박씨(고흥산)는 이마트에서 구입하여 $55^{\circ} \mathrm{C}$ 에서 12 시간 열풍건조한 후 마쇄하여 $100 \mathrm{mesh}$ 이하의 분말 로 제조하여 시료로 사용하였다. 찹쌀가루(뚜레반), 설탕 (제일제당), 정제염(대상), 감자 등은 시중 농협에서 구입하 여 사용하였다.

\section{호박의 황국균 발효}

실험에 사용하는 황국균(Aspergillus oryzae)은 amylase, protease, lipase 등 다양한 가수분해효소를 체외로 분비하는 균으로 우리나라 전통발효식품에 널리 이용되고 있는 식용 가능한 안전한(GRAS) 균이다. 황국균이 호박죽에 사용할 각종 재료에서 생육이 가능한지 여부를 알아보기 위하여 늙은호박, 단호박, 호박씨, 호박잎의 4 가지의 호박원료를 사용하였다. 호박 배지조제는 각종 원료를 $25-35 \%$, 한천 $1.5 \%$, 물 73.5-63.5\%를 혼합하여 고압증기 멸균 $\left(121^{\circ} \mathrm{C}, 1.3\right.$ 기압, 15 분)이 끝난 후, 무균상자에서 petri dish에 분주하여 굳혀서 호박배지를 제조하였다.

Potato dextrose agar(PDA)에서 순수 배양하여 활성화된 황국균( $A$ oryzae)의 포자를 접종하였다. 호박 원료 25-35\% 함유한 고체배지에 황국균의 포자를 접종하여 $30^{\circ} \mathrm{C}$ 배양기 에서 4일간 배양하면서 생육을 조사하였다.

\section{단백질 분해효소 실험}

호박죽의 발효 전과 발효 후 단백질 분해효소 활성을 비교하기 위해 skim milk agar(Difco, Sparks, MD, USA) 배지에 호박죽 시료를 발효 전과 발효 후로 나누어 멸균수 에 같은 농도로 희석하여 희석한 발효액을 $50 \mu \mathrm{L}$ 씩 접종하 고 $35^{\circ} \mathrm{C}$ 에서 30 시간 배양 후 단백질을 분해한 정도를 관찰 하였다.

\section{전분 분해효소 실험}

호박죽의 발효 전과 발효 후 전분 분해효소 활성을 비교 하기 위해 starch agar(Difco) 배지에 호박죽 시료를 발효 전과 발효 후로 나누어 멸균수에 같은 농도로 희석하여 희석한 발효액을 $50 \mu \mathrm{L}$ 씩 접종하고 $35^{\circ} \mathrm{C}$ 에서 20 시간 배양 후 요오드액을 부어 전분을 분해한 정도를 관찰하였다.

\section{발효 호박죽 제조 공정}

발효 호박을 제조하기 위한 공정은 다음과 같다. 원료를 손질하여 이물질 제거한 후 각각의 원료를 분쇄하여, 비율 대로 혼합하였다. 이후 황국균이 잘 자랄 수 있도록 수분을 보충하기 위해서 원료 중량의 $50 \%$ 멸균수를 혼합하여 주었 다. 수분 보충 후 원료의 $0.1 \%$ 함량의 황국균을 접종하고, 균 접종 후 $30^{\circ} \mathrm{C}$ 에서 4 일간 발효하였다. 발효가 끝난 후 $60^{\circ} \mathrm{C}$ 에서 3 일간 건조하여 분쇄한 후 사용하였다.

발효 호박죽을 제조하기 위한 재료 배합비는 Table 1과 같다. 주재료(호박, 호박잎, 호박씨) 함량 $65 \%$ 중 호박잎과 
씨 각각 $0.25 \%$ 첨가한 시료 $(0.5 \%)$, 각각 $0.5 \%$ 씩 첨가한 시료 $(1.0 \%)$, 각각 $1.0 \%$ 씩 첨가한 시료 $(2 \%)$ 를 발효과정을 거쳐 제조한 분말과, $1.0 \%$ (호박잎과 호박씨 각각 $0.5 \%$ ) 첨 가하여 제조한 분말(비발효) 시료를 대조구로 사용하다.

Table 1. Making formula for preparation of instant pumpkin gruel containing different amount of fermented pumpkin powder

(unit: \%)

\begin{tabular}{ccccc}
\hline & \multicolumn{4}{c}{ Substitution level of pumpkin powder ${ }^{1)}$} \\
\cline { 2 - 5 } & Control & $0.5 \%$ & $1.0 \%$ & $2.0 \%$ \\
\hline Pumpkin & 64.0 & 64.5 & 64.0 & 63.0 \\
Pumpkin leaf & 0.5 & 0.25 & 0.5 & 1.0 \\
Pumpkin seed & 0.5 & 0.25 & 0.5 & 1.0 \\
Starch & 20 & 20 & 20 & 20 \\
Sugar & 14 & 14 & 14 & 14 \\
Salt & 1 & 1 & 1 & 1 \\
\hline Total & 100 & 100 & 100 & 100 \\
\hline
\end{tabular}

${ }^{1)}$ Control, pumpkin powder contents before the fermentation; $0.5-2.0 \%$, pumpkin powder contents after the fermentation.

\section{일반성분}

호박 열매, 잎과 씨앗을 발효시켜 일정 비율 첨가하여 제조한 호박죽의 일반성분은 $\mathrm{AOAC}$ 방법(18)과 식품공전 (19)에 따라 분석하였다. 즉, 수분은 상압가열건조법, 조회 분은 건식회화법, 조지방은 Soxhlet 추출법, 조단백질은 Micro kjeldahl 법으로 각각 분석하였다.

\section{총 당}

발효 호박죽 분말의 총당은 phenol-sulfuric acid법으로 분석하였다(20). 시료 일정량을 취하여 균질화하고 증류수 $50 \mathrm{~mL}$ 로 정용하고 원심분리 후 여과하였다. 여액 $1 \mathrm{~mL}$ 를 $100 \mathrm{~mL}$ 로 정용한 시료 용액 $1 \mathrm{~mL}$ 에 $5 \%$ phenol 용액 1 $\mathrm{mL}$ 를 가하여 혼합하고 $\mathrm{H}_{2} \mathrm{SO}_{4}$ 용액 $5 \mathrm{~mL}$ 를 가하여 10 분간 방치한다. 이를 $20-30{ }^{\circ} \mathrm{C}$ 의 water bath(JSWB-22T, JS Research Inc., Gongju, Korea) 에서 20분간 유지한 후 spectrophotometer(UV/VIS spectrometer, Lambda 25, Perkin Elmer, Shelton, USA) $470 \mathrm{~nm}$ 에서 흡광도를 측정하였다. 표준물질은 맥아당(Yakuri Pure Chemicals Co., Ltd., Osaka, Japan)을 사용하여 검량선을 작성 한 후 시료 중 총당 함량 을 구하였다.

\section{유리당}

유리당은 Gancedo 등의 방법(21)에 따라 시료에 증류수 를 가하여 실온에서 4시간 추출한 다음 추출물을 Sep-pak $\mathrm{C}_{18}$ cartridge로 정제한 후 $0.45 \mu \mathrm{m}$ membrane filter로 여과한 후 High performance liquid chromatography(HPLC-RID, Shiseido nanospace SI-2, Japan)를 이용하여 컬럼은 carbohydrate analysis(3.9×300 mm), 주입량은 $20 \mu \mathrm{L}$, 용매는 water:acetonitrile(17:83)으로 $1.0 \mathrm{~mL} / \mathrm{min}$ 의 속도로 분석하 였다.

\section{색 도}

색도는 색차계(Color and color difference meter, Model No. TC-3600, Tokyo Denshoku Co., Ltd., Tokyo, Japan)로 측정하여 Hunter system 의 3 자극치인 명암도를 나타내는 $\mathrm{L}$ (lightness) 값, 적색도의 정도를 나타내는 a(redness) 값, 황색도의 정도를 나타내는 $\mathrm{b}$ (yellowness) 값으로 나타내었 다(22). 이때 사용한 표준백판은 $\mathrm{L}=90.5, \mathrm{a}=0.4, \mathrm{~b}=3.5$ 였다.

\section{통계처리}

각 실험은 3회 반복하여 얻은 결과를 평균과 표준편차로 나타내었으며, 그 결과는 SAS package로 통계처리(23)하였 으며, 시료간의 유의검증은 Duncan's multiple range test로 검증하였다.

\section{결과 및 고찰}

\section{단백 분해효소 활성}

호박죽의 발효 전과 발효 후 단백질 분해 효소 활성을 비교하기 위해 skim milk agar 배지에 호박죽 시료를 발효 전과 발효 후로 나누어 멸균수에 같은 농도로 희석한 발효 액을 $50 \mu \mathrm{L}$ 씩 접종하고 $35^{\circ} \mathrm{C}$ 에서 30 시간 배양 후 단백질을 분해한 정도를 관찰한 결과는 Fig. 1과 같다. Paper disk 주변의 투명환이 클수록 단백질 분해능이 크다는 것을 의미 한다. 실험 결과 발효 전과 발효 후 단백질이 분해되어 투명 환의 크기 차이를 관찰할 수 있었으며, 발효 후 배지에서 단백질 분해 효소활성이 우수함을 알 수 있었다.

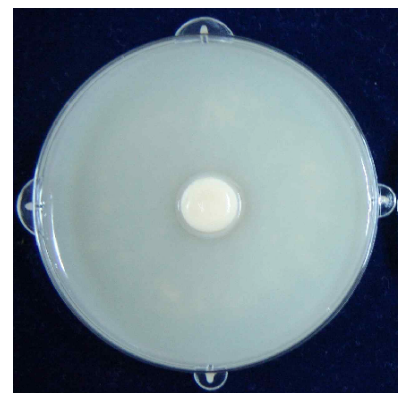

Before the fermentation

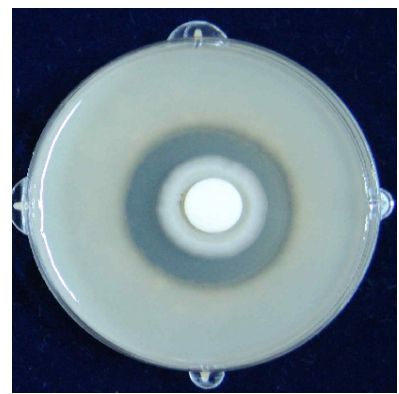

After the fermentation
Fig. 1. Proteolytic activity of $A$ oryzae in skim milk plate at $35^{\circ} \mathrm{C}$ for $30 \mathrm{~h}$.

\section{전분 분해효소 활성}

호박죽의 전분 분해효소 활성을 비교하기 위해 starch agar 배지에 호박죽 시료를 발효 전과 발효 후로 나누어 
멸균수에 같은 농도로 희석한 발효액을 $50 \mu \mathrm{L}$ 씩 접종하고 $35^{\circ} \mathrm{C}$ 에서 20 시간 배양 후 요오드액을 부어 균이 전분을 분해한 정도를 관찰한 결과는 Fig. 2 와 같다. 전분이 분해가 되면 요오드액을 부었을 때 발효액을 접종한 주위에 투명한 환이 생기며, 투명환이 클수록 amylase 전분 분해능이 크다 는 것을 의미한다. 결과에서 발효 전과 발효 후 전분이 분해 되어 투명환의 크기 차이를 관찰할 수 있었으며, 발효 후 amylase 전분 분해효소 활성이 우수함을 알 수 있었다.

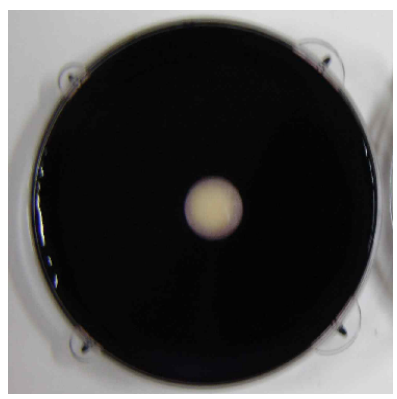

Before the fermentation

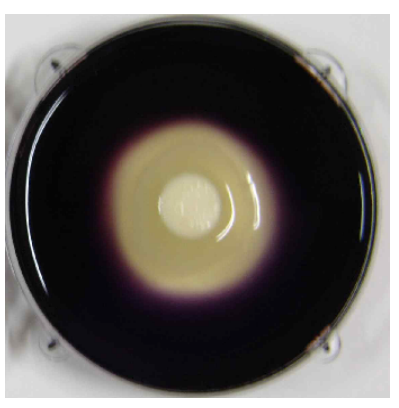

After the fermentation
Fig. 2. Amylase activity of $A$ oryzae in starch agar plate at $35^{\circ} \mathrm{C}$ for $20 \mathrm{~h}$.

\section{일반성분}

발효 호박죽의 일반성분을 분석한 결과는 Table 2 와 같 다. 대조구인 호박 재료를 $65 \%$ (호박 $64 \%$, 호박잎과 호박씨 각각 $0.5 \%$ )를 첨가하여 제조한 분말과 $0.5 \%$ (호박 $64.5 \%$, 호박잎과 씨 $0.25 \%$ 씩 첨가), $1.0 \%$ (호박 $64.0 \%$, 호박잎과 씨 $0.5 \%$ 씩 첨가), $2 \%$ (호박 $63.0 \%$, 호박잎과 씨 각각 $1.0 \%$ 첨가)로 부위별 호박 함량을 달리하여 혼합한 후 발효과정 을 거쳐 제조한 분말의 일반성분은 탄수화물 $75.40-76.94 \%$, 조단백질 7.57-8.96\%, 수분 6.35-7.42\%, 조지방 $4.12-5.16 \%$, 회분 4.28-4.45\%의 함량을 보였다. 수분함량을 제외한 전체 건물량을 기준으로 영양성분을 비교한 결과에서도 비슷한 결과를 보여 탄수화물, 조단백질, 조지방, 회분 순이었다.

첨가 수준별 발효 호박죽 시료의 경우 발효 전 시료인 대조구에 비해 탄수화물과 조단백질 함량을 증가하는 경향 을 보였고, 수분, 조지방 함량은 조금 감소하였으며 회분 함량은 변하지 않은 것으로 나타났다. 이러한 결과는 호박 열매, 잎과 씨 첨가량 비율과는 무관한 것으로 판단된다.

수분함량을 제외한 전체 건물량을 기준으로 영양성분을 비교한 결과에서, 탄수화물 함량은 분말 첨가량이 증가할 수록 다소 증가하는 경향을 보였으며, 조단백질과 조지방 함량은 큰 차이는 아니지만 감소하였으며, 회분 함량은 변 화를 보이지 않은 것으로 나타났다.

Jo 등(24)은 호박죽의 재료와 배합비에 따른 영양성분을 분석한 결과 수분을 제외한 건물량을 기준으로 탄수화물 함량이 65.71-82.83\%라고 보고하여 본 실험 결과와 유사한 결과를 보였으나, 조단백질과 조지방 함량의 경우 조금 낮
은 결과를 보고하였다.

Table 2. Proximate compositions of instant pumpkin porridge containing different amount of fermented pumpkin powder

\begin{tabular}{ccccc}
\multicolumn{4}{c}{ Substitution level of pumpkin powder } \\
\hline & Control & $0.5 \%$ & $1.0 \%$ & $2.0 \%$ \\
\cline { 2 - 5 } Moisture & $7.42 \pm 0.12^{2)}$ & $6.35 \pm 0.04$ & $6.38 \pm 0.05$ & $6.43 \pm 0.24$ \\
& $7.57 \pm 0.14$ & $8.96 \pm 0.11$ & $8.57 \pm 0.22$ & $8.17 \pm 0.44$ \\
Crude protein ${ }^{3)}$ & $(8.18)^{4)}$ & $(9.57)$ & $(9.15)$ & $(8.73)$ \\
& $5.16 \pm 0.17$ & $4.71 \pm 0.20$ & $4.38 \pm 0.10$ & $4.12 \pm 0.05$ \\
Crude lipid & $(5.57)$ & $(5.03)$ & $(4.68)$ & $(4.40)$ \\
& $4.45 \pm 0.11$ & $4.43 \pm 0.14$ & $4.28 \pm 0.04$ & $4.34 \pm 0.13$ \\
Ash & $(4.81)$ & $(4.73)$ & $(4.57)$ & $(4.64)$ \\
& $75.40 \pm 0.92$ & $75.55 \pm 0.54$ & $76.39 \pm 0.63$ & $76.94 \pm 0.66$ \\
Carbohydrate & $(81.44)$ & $(80.67)$ & $(81.54)$ & $(82.23)$ \\
& &
\end{tabular}

${ }^{11}$ Control, pumpkin powder contents before the fermentation; $0.5-2.0 \%$, pumpkin powder contents after the fermentation.

${ }^{2}$ Mean \pm SD ( $=3$ ).

${ }^{3)} \mathrm{N} \times 6.25$.

4) ( ), Content of crude protein, crude lipid, ash and carbohydrate were calculates on a dry basis.

${ }^{5} 100$-(sum of moisture, crude protein, crude lipid and ash)

총 당

시료별 총당을 측정한 결과(Table 3), 발효 전 대조구가 $26.23 \pm 2.15 \%$ 으로 가장 높게 나타났으며, 발효 후 시료는 18.31-19.05\%로 발효 처리를 한 시료의 경우 총당 함량이 전체적으로 낮아지는 결과를 보였다. 첨가 비율에 따른 결 과는 $0.5 \%$ 첨가 발효 호박죽이 $18.76 \pm 0.97 \%, 2 \%$ 첨가 시료 가 $18.31 \pm 1.35 \%$ 로 시료 간 큰 차이를 보이지 않은 것으로 나타났다.

Table 3. Total sugar and free sugar contents of instant pumpkin gruel containing different amount of fermented pumpkin powder

(unit: \%)

\begin{tabular}{ccccc}
\hline & \multicolumn{4}{c}{ Substitution level of pumpkin powder ${ }^{1)}$} \\
\cline { 2 - 5 } & Control & $0.5 \%$ & $1.0 \%$ & $2.0 \%$ \\
\hline Total sugar & $26.23 \pm 2.15^{2)}$ & $18.76 \pm 0.97$ & $19.05 \pm 1.21$ & $18.31 \pm 1.35$ \\
\hline Glucose & $8.81 \pm 0.53$ & $8.84 \pm 1.35$ & $9.22 \pm 1.67$ & $9.16 \pm 1.72$ \\
Fructose & $7.32 \pm 0.32$ & $5.40 \pm 0.71$ & $5.58 \pm 0.99$ & $5.73 \pm 0.86$ \\
Sucrose & $20.41 \pm 0.92$ & $0.70 \pm 0.06$ & $0.92 \pm 0.03$ & $0.75 \pm 0.03$ \\
\hline Sum & $36.54 \pm 1.41$ & $14.94 \pm 0.85$ & $15.72 \pm 1.06$ & $15.64 \pm 0.89$ \\
\hline
\end{tabular}

${ }^{1)}$ Control, pumpkin powder contents before the fermentation; $0.5-2.0 \%$, pumpkin powder contents after the fermentation.

${ }^{2)} \mathrm{Mean} \pm \mathrm{SD}(\mathrm{n}=3)$

\section{유리당}

호박의 부위별 함량을 달리한 시료의 유리당 함량을 분 석한 결과는 Table 3 과 같다. 분석한 유리당은 glucose, 
fructose와 sucrose이며, 3 종의 유리당을 분석한 결과 모든 시료에서 검출이 되었다. Glucose의 경우 발효 전과 후의 함량이 차이를 보이지 않은 것으로 나타났고, fructose와 sucrose는 발효 전 함량에 비해 발효를 시킨 호박죽 분말에 서 함량이 낮아졌으며, 특히 sucrose 함량은 발효에 의해 크게 감소하는 것으로 나타났다.

총 유리당 함량에서도 대조구가 $36.54 \pm 1.41 \%$ 로 가장 높은 결과를 보였으며, 발효처리를 한 시료의 경우 $14.93-15.72 \%$ 로 크게 감소하였다. 이는 sucrose 함량 감소가 가장 주된 이유로 나타났으며, 총당 측정 결과 발효과정에 따라 함량이 감소하는 결과와 비슷한 것으로 나타났다.

$\mathrm{Kim}$ 등(25)은 당 첨가 민들레 발효 추출물의 발효과정 중 유리당 함량 변화를 측정한 결과 발효 및 숙성 과정을 거치면서 발효 과정 중에 생육되는 미생물의 영양원, 유산 발효, 유기산 발효의 기질로 당이 이용되었기 때문에 유리 당 함량이 감소된 것으로 판단된다고 보고하여 본 실험 결과와 비슷하였다.

\section{색 도}

호박을 주재료로 하고 잎과 씨앗을 일정 비율로 첨가하 여 제조한 분말 호박죽의 색도를 측정한 결과(Table 4), 명도 를 나타내는 $\mathrm{L}$ 값은 발효과정을 거치지 않은 분말의 경우 71.21 이었으며, 발효과정을 거친 제품의 경우 $0.5 \%$ 첨가구 가 $71.39,1 \%$ 첨가구가 $71.06,2 \%$ 첨가구가 69.70 으로 조금 낮아지는 결과를 보였으며, 이는 발효에 따른 결과보다는 재료의 첨가량에 따라 달라진다고 판단된다. 적색도를 나 타내는 $\mathrm{a}$ 값과 황색도를 나타내는 $\mathrm{b}$ 값의 경우 발효유무에 따라 값이 차이를 보여 모두 낮아지는 결과를 보였으나, 재료별 첨가량에 따른 차이는 관찰되지 않은 것으로 나타 났다.

발효과정을 거치지 않은 시료와 발효과정을 거친 시료간 의 색차값을 비교한 $\Delta \mathrm{E}$ 값의 변화는 $0.5 \%$ 첨가한 발효 호박죽 분말이 10.09 로 나타났으며 $1.0 \%$ 첨가시료가 8.96 , $2.0 \%$ 첨가시료가 10.34 로 나타나 natural bureau of standard(NBS)의 기준(26)에 따라 상당한 변화가 있는 것으

Table 4. Hunter's color value of instant pumpkin gruel containing different amount of fermented pumpkin powder

\begin{tabular}{ccccc}
\hline & \multicolumn{4}{c}{ Substitution level of pumpkin powder ${ }^{1)}$} \\
\cline { 2 - 5 } & Control & $0.5 \%$ & $1.0 \%$ & $2.0 \%$ \\
\hline L (lightness) & $71.21 \pm 0.43^{2)}$ & $71.39 \pm 0.41$ & $71.06 \pm 0.51$ & $69.70 \pm 0.53$ \\
a (redness) & $6.96 \pm 0.66$ & $3.16 \pm 0.52$ & $3.20 \pm 0.52$ & $2.89 \pm 0.49$ \\
b (yellowness) & $58.89 \pm 0.61$ & $49.54 \pm 1.01$ & $50.76 \pm 0.99$ & $49.50 \pm 0.31$ \\
$\Delta \mathrm{E}^{3)}$ & 0 & 10.09 & 8.96 & 10.34 \\
\hline
\end{tabular}

${ }^{1)}$ Control, pumpkin powder contents before the fermentation; $0.5-2.0 \%$, pumpkin powder contents after the fermentation.

${ }^{2)}$ Mean \pm SD ( $\left.n=3\right)$.

${ }^{3)} \Delta \mathrm{E}=$ overall color difference.
로 간주되는 3.0 이상의 값을 보여 발효과정이 분말 고유의 색에 영향을 주는 것으로 나타났다. 호박잎과 씨앗 함량에 따른 색차값의 경우에는 시료 간 거의 차이를 보이지 않아 함량이 분말의 색에 영향을 주지 않은 것으로 보인다. NBS 기준에서 나타내는 색차값의 범위는 0-0.5, 0.5-1.5, 1.5-3.0 이면 각각 trace, slight, noticeable한 정도의 육안적인 차이 에 해당한다. NBS 기준은 감각적인 색의 차이와 잘 대응하 므로 널리 이용되고 있으며, 일반적인 사람이 떨어져 있는 2 색에 차이가 없다고 인정하는 색의 허용 차이는 $\Delta \mathrm{E} \leqq 3$ 이라고 보고되어 있다(27).

\section{요 약}

호박의 부산물인 호박잎과 씨를 첨가하여 제조한 호박죽 과, 발효 공정을 첨가하여 제조한 발효 호박죽 제품의 영양 학적 특성을 조사한 결과는 다음과 같다. 호박죽의 발효 전과 발효 후 단백질 및 전분 분해효소 활성을 비교한 결과, 발효 후 배지에서 단백질 및 전분 분해효소 활성이 우수함 을 알 수 있었다. 주재료(호박, 호박잎, 호박씨) 함량 $65 \%$ 중 호박잎과 씨를 각각 $0.25 \%$ 첨가한 시료 $(0.5 \%), 0.5 \%$ 씩 첨가한 시료(1.0\%), $1.0 \%$ 씩 첨가한 시료(2\%)를 발효과정을 거쳐 제조한 분말과, $1.0 \%$ (호박잎과 호박씨 각각 $0.5 \%$ 첨 가)로 제조한 분말(비발효, 대조구)의 일반성분 분석 결과, 발효 호박죽 시료의 경우 대조구에 비해 탄수화물과 조단백 질 함량이 증가하였고, 수분, 조지방 함량은 감소하였다. 총당 분석 결과, 대조구 $(26.23 \pm 2.15 \%)$ 시료가 가장 높았으 며, 발효 후 시료(18.31\%-19.05\%)는 낮아지는 결과를 보였 다. Glucose, fructose와 sucrose 등 유리당 함량은 모든 시료 에서 검출이 되었으며, fructose와 sucrose 함량은 발효 시료 에서 감소하였고, 특히 sucrose 함량은 크게 감소하였다. 총 유리당 함량은 대조구 $(36.54 \pm 1.41 \%)$ 가 가장 높았으며, 발효처리 시료의 경우 $14.93-15.72 \%$ 로 크게 감소하였고, sucrose 함량 감소가 주원인이었으며, 이는 총당 결과 발효 과정에 따라 함량이 감소하는 결과와 일치하였다. 색도 측 정결과, $\mathrm{L}$ 값(명도)은 대조구 비해 발효과정을 거친 제품의 경우 조금 낮아지는 결과를 보였으나, 이는 발효 유무보다 는 재료의 첨가량에 따라 영향을 받는 것으로 판단된다. $\mathrm{a}$ 값(적색도)과 $\mathrm{b}$ 값(황색도)의 경우 발효 유무에 따라 차이 를 보여 낮아지는 결과를 보였다. 시료간의 색차값을 비교 한 $\Delta \mathrm{E}$ 값은 $0.5 \%$ 첨가한 발효 호박죽 분말이 $10.09,1.0 \%$ 첨가시료가 $8.96,2.0 \%$ 첨가시료가 10.34 로 나타나 발효과 정이 분말 고유의 색에 영향을 주는 것으로 나타났다. 따라 서 호박죽을 제조할 때 호박잎과 호박씨를 각각 $1.0 \%$ 정도 첨가하여 발효처리를 한 호박죽의 제품이 가장 좋을 것으로 판단된다. 


\section{감사의 글}

본 연구는 「2015년 고흥로컬푸드향토사업단」의 연구 비지원에 의하여 수행되었으며, 이에 감사드립니다.

\section{References}

1. Lee JM, Park DK, Kwon YM (2011) Pumpkin-fall in love with pumpkins. National Institute of Horticultural and Herbal Science Rural Development Administration, Suwon, Korea, p 128-129

2. Kim HA, Kim JH (2015) Optimization of Hobakjook (pumpkin soup) with added glutinous rice powder. J East Asian Soc Diet Life, 25, 162-175

3. Jeong DH (2000) Foods to prevent cancer. Yuhan book, Seoul, Korea, p 9

4. Nakagawa Yujo (2000) Vegetable dictionary. People \& Book, Seoul, Korea, p 24

5. Ministry of Health and Welfare. Korean health statistics (2011) Korea national health and nutrition examination survey. Ministry of health and welfare, Seoul, Korea, p 317-331

6. Rural Development Administration (2011) National Academy of Agricultural Science $8^{\text {th }}$ revision. Food composition table, Suwon, Korea, p 182-183

7. Kim MJ, Hong CO, Nam MH, Lee KW (2011) Antioxidant effects and physiological activities of pumpkin (Cucurbita moschata Duch.) extract from different aerial parts. Korean J Food Sci Technol, 43, 195-199

8. Kwak YE, Ju JH (2013) Antioxidant and anticancer activities of squash (Cucurbita moschata Duch.) leaf extract in vitro. Korean J Food Sci Technol, 45, 770-776

9. Cha YY (2009) Experimental study on effects of Cucurbita moschata Duch. on antioxidation. J Soc Korean Med Obes Res, 9, 57-63

10. Procida G, Stancher B, Cateni F, Zacchingna M (2013) Chemical composition and functional characterization of commercial pumpkin seed oil. J Sci Food Agric, 93, 1035-1041

11. Sales-Campos H, Souza PR, Peghini BC, da Silva JS, Cardoso CR (2013) An overview of the modulatory effects of oleic acid in health and disease. Mini Rev Med Chem, 13, 201-210

12. Zhao G, Etherton TD, Martin KR, Vanden Heuvel JP, Gillies PJ, West SG, Kris-Etherton PM (2005)
Anti-inflammatory effects of polyunsaturated fatty acids in THP-1 cells. Biochem Biophys Res Commun, 336, 909-917

13. Sim HS, Jang BC, Park HM, Jeng BY, Oh MJ (2008) Isolation of cucurbitacin $\mathrm{E}$ from sprouted pumpkin seed and analysis of its anti-cancer and anti-inflammatory activities. J Korean Soc Food Sci Nutr, 37, 834-840

14. Yoon SS (2002) Korean Food: History and recipes. Suhaksa, Seoul, Korea, p 86

15. June JH, Yoon JY, Kim HS (1998) A study on the preference of Korean traditional Jook Korean J Diet Cult, 13, 497-507

16. Jo HJ (1992) Material changes in the ratio of symbols according to Hobakjuk Ms Thesis, Sookmyung Women's University, Korea, p 18

17. Shin DS, Park BR, Yoo SM, Hwang Y (2013) The optimization of instant pumpkin gruel with pumpkin powder using response surface methodology. Korean $\mathbf{J}$ Food Cookery Sci, 29, 291-300

18. AOAC (1990) Official Methods of Analysis. $15^{\text {th }}$ ed, Association Official Analytical Chemists, Washington DC, USA, p 157

19. KFDA (2005) Food Code. A separate volume. Munyoung-sa, Seoul, Korea, p 3-29

20. Dubois M, Gilles KA, Hamilton JK, Robers PA, Smith F (1956) Calorimetric method for determination of sugars and related substances. Anal Chem, 28, 350-356

21. Gancedo M, Luh BS, (1986) HPLC analysis of organic acids and sugars in tomato juice. J Food Sci, 51, 571-573

22. Choi HC, OH SK (1996) Diversity and function of pigments in colored rice. Korean J Crop Sci, 41, 1-9

23. Wang H, Cao G, Prior RL (1997) Oxygen radical absorbing capacity of anthocyanins. J Agric Food Chem, 45, 304-309

24. Cho HJ, Ahn CK, Yum CA (1996) A study on the preference of Hobakjook upon material \& mixing ratio change. Korean J Soc Food Sci, 12, 146-152

25. Kim KM, Kim YN, Choi BK, Oh DH (2012) Physicochemical and microbiological changes of the fermented dandelion (Taraxacum officinale) extracts with raw sugar. Korean J Food Preserv, 19, 131-137

26. Lee CH (1995) Food Industry Quality Control. Yurimmunhwasa, Seoul, Korea, p 279

27. Judd DG, Wyszecki G (1964) Applied colorific science for industry and business. Diamond Co, Tokyo, Japan, p 333-334 